\title{
Morphological plasticity in Myxobolus Bütschli, 1882: a taxonomic dilemma case and renaming of a parasite species of the common carp
}

Qingxiang Guo ${ }^{1,2}$, Mingjun Huang ${ }^{1,2}$, Yang Liu ${ }^{1,2}$, Xiuping Zhang ${ }^{1,2}$ and Zemao Gu $u^{1,2^{*}}$

\begin{abstract}
Background: Myxozoans are a group of cnidarian parasites, the present taxonomy of which favors a more comprehensive characterization strategy combining spore morphology, biological traits (host/organ specificity, tissue tropism), and DNA data over the classical morphology-based taxonomy. However, a systematist might again run into a taxonomic dilemma if more than two of the following exceptional cases were encountered at the same time: extensive intraspecific polymorphism, interspecific morphological similarity, identical interspecific biological traits and blurred small-subunit (SSU) rDNA-based species boundaries. In the present study, spores of a species of Myxobolus Bütschli, 1882 with two morphotypes (wide type and narrow type) were collected from the gills of common carp Cyprinus carpio Linnaeus. Confusingly, the wide type was found to be identical to Myxobolus paratoyamai Kato, Kasai, Tomochi, Li \& Sato, 2017 in spore morphology and SSU rDNA sequence, which confidently suggested their conspecificity; while the narrow type, was highly similar to Myxobolus toyamai Kudo, 1917 based on spore morphology and SSU rDNA sequence and thus could not be easily classified. This discordance between wide type and narrow type has caused a taxonomic dilemma. To address this problem, a hypothesis about the conspecificity of the narrow type and M. toyamai was addressed.
\end{abstract}

Results: It was found that if the narrow type is conspecific with M. toyamai, it would be paradoxical for the SSU rDNA sequence of the narrow type to be more similar to M. paratoyamai (99.3\%), Myxobolus acinosus Nie \& Li, 1973 (98.6\%) and Myxobolus longisporus Nie \& Li, 1992 (98.7\%) than to M. toyamai (97.6\%). According to the results of the above what-if analysis, the narrow type and $M$. toyamai were considered to be different species. All in all, the present dual-morphotype species is estimated to be conspecific with M. paratoyamai Kato, Kasai, Tomochi, Li \& Sato, 2017. Considering that this species name was preoccupied by Myxobolus paratoyamai Nie \& Li, 1992, the replacement name Myxobolus pseudoacinosus nom. nov. is proposed.

Conclusions: This work addresses the taxonomic dilemma in polymorphic myxozoans and demonstrates that $M$. pseudoacinosus is a distinct species with two morphotypes. The present study may serve as a baseline for future studies that encounter similar classification complexities.

Keywords: Myxozoan, Myxobolus pseudoacinosus, Morphotype, SSU rDNA, Taxonomic dilemma, Tissue tropism

\footnotetext{
* Correspondence: guzemao@mail.hzau.edu.cn

'Department of Aquatic Animal Medicine, College of Fisheries, Huazhong

Agricultural University, Wuhan, Hubei Province 430070, People's Republic of

China

${ }^{2}$ Hubei Engineering Technology Research Center for Aquatic Animal Diseases

Control and Prevention, Wuhan, Hubei Province 430070, People's Republic of

China
}

(C) The Author(s). 2018 Open Access This article is distributed under the terms of the Creative Commons Attribution 4.0 International License (http://creativecommons.org/licenses/by/4.0/), which permits unrestricted use, distribution, and reproduction in any medium, provided you give appropriate credit to the original author(s) and the source, provide a link to the Creative Commons license, and indicate if changes were made. The Creative Commons Public Domain Dedication waiver (http://creativecommons.org/publicdomain/zero/1.0/) applies to the data made available in this article, unless otherwise stated. 


\section{Background}

Myxozoans are widespread cnidarian parasites with over 2400 species recorded [1]. Most of them were initially described using traditional taxonomy methods based solely on spore morphology [2]. Later on, myxozoan systematists resorted to also using host preference/tissue specificity to aid in resolving taxonomic problems, with the awareness that most myxozoans tend to be oioxenic and have preference for certain developmental sites [3-5]. Moreover, the molecular methods involving genetic markers have boomed in the past decade and provided a more comprehensive solution to resolving morphologically indistinguishable species by taking advantage of their fidelity and quantifiability $[4,6]$. Taken together, the above three criteria (spore morphology, biological traits and DNA data) have constituted a well-accepted framework for myxozoan classification [7].

However, there are exceptional cases that involve extensive intraspecific polymorphism, interspecific morphological similarity, identical interspecific biological traits, and blurred SSU rDNA-based species boundaries [8-11]. In these situations, if more than two of above exceptional cases are encountered at the same time, a systematist might again run into what we call a "taxonomic dilemma". Unfortunately (fortunately?), this is the exact situation that we are facing.

In the present study, a species of Myxobolus with two morphotypes (wide type and narrow type) was collected from the gills of the common carp Cyprinus carpio Linnaeus. Paradoxically, the wide-type spores were found to be identical to Myxobolus paratoyamai Kato, Kasai, Tomochi, Li \& Sato, 2017 based on spore morphology and SSU rDNA sequence, while the narrow-type spores were highly similar to Myxobolus toyamai Kudo, 1917 both in spore morphology and SSU rDNA sequence. Three of the four above mentioned exceptional cases (intraspecific polymorphism, interspecific morphological similarity and blurred SSU rDNA-based species boundaries) were herein encountered and created this taxonomic dilemma. In order to resolve the current uncertainties in species identification, the present material was characterized considering both morphology and molecular biology data and was subsequently determined to be conspecific with M. paratoyamai [12], with the additional trait of having two morphotypes.

\section{Methods}

\section{Fish sampling and morphological analysis}

Common carp C. carpio were sampled from the Baishazhou Fish Market, Wuhan, China in January 2013 ( $n=34$; total length 16-24 cm) and April $2015(n=$ 4; total length $23-28 \mathrm{~cm}$ ). Fish were sent to the laboratory and kept in a relaying tank prior to being euthanized with an overdose of MS-222 (Sigma-Aldrich, Co., Ltd., St.
Louis, MO., USA). Parasitological examinations were then conducted on the specimens and fresh myxospores were visualized and photographed under an Olympus BX53 light microscope using Nomarski differential interference contrast and, equipped with an Olympus DP73 digital camera (Olympus, Hamburg, Germany). Myxozoan identification and morphological analysis were performed following the formerly developed guidelines [13] based on morphometric measurements of 40 fresh mature spores. All measurements are shown in micrometres $(\mu \mathrm{m})$ as the range, followed by the mean $\pm \mathrm{SD}$ in parentheses.

\section{Histopathological examination and ultrastructure}

Fish gills containing plasmodia were fixed with Bouin's solution, gradient-dehydrated, embedded in paraffin wax and sectioned at $4 \mu \mathrm{m}$, and stained with haematoxylin and eosin. For transmission electron microscopy, tissues containing the plasmodia were excised and the following fixation, dehydration, embedment and staining steps were conducted according to the protocol of Liu et al. [14]. Double-stained sections were visualized and photographed using a $200 \mathrm{kV}$ transmission electron microscope (Tecnai G20 TWIN, FEI company, OR, USA).

\section{DNA extraction, amplification and sequencing}

Ethanol-preserved plasmodia were used for genomic DNA extraction according to the protocols recommended by the manufacturer of the TIANamp Genomic DNA Kit (Beijing Tiangen Biotech Co. Ltd., China). The SSU rRNA gene was amplified with universal eukaryotic primer pairs 18e [15] and 18r [16], for spores collected in 2015 (narrow type), or MyxospecF [17] and SphR [18], for spores collected in 2013 (wide type). The next step of PCR, purification, cloning and transformation were performed following the procedure of Zhao et al. [19]. DNA sequences were then defined bidirectionally by Sanger sequencing on an ABI PRISM ${ }^{\circledR} 3730$ sequencer (Applied Biosystems Inc., Foster, USA), with the resulting contiguous sequences assembled by the Lasergene package v 5. 05 (DNASTAR, Madison, Wisconsin) and corrected with BioEdit 7.2.5 [20] based on the original sequence chromatograms. Contiguous sequences were then submitted to an NCBI BLASTn search for comparison with other myxozoan sequences.

\section{Phylogenetic and distance analysis}

The newly acquired SSU rDNA sequences of $M$. pseudoacinosus and 79 other myxozoan sequences retrieved from GenBank were used for phylogenetic analysis. Myxidium streisingeri Whipps, Murray \& Kent, 2015 (GenBank: KM001688) was selected as the outgroup. Alignments were performed with MAFFT v7.305b [21] using default parameters. Gblocks [22] was used to remove unreliably aligned regions (with the following 


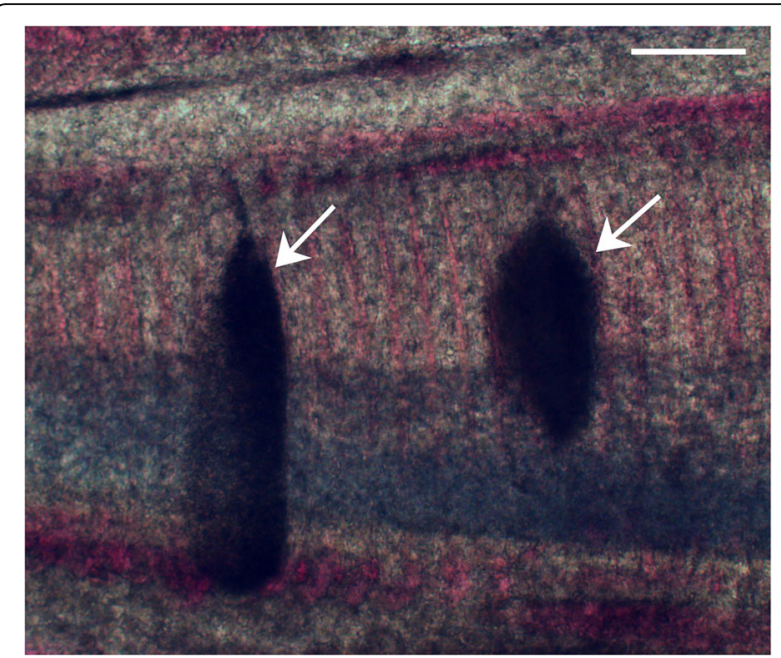

Fig. 1 Gills of the common carp Cyprinus carpio heavily infected with Myxobolus pseudoacinosus. Note the plasmodia (arrows). Scalebar: $300 \mu \mathrm{m}$

parameters: $-\mathrm{t}=\mathrm{d},-\mathrm{b} 1=41,-\mathrm{b} 2=41,-\mathrm{b} 3=10,-\mathrm{b} 4=2$, -b5 $=\mathrm{a}$ ), resulting in a final data set of 81 taxa and 1713 positions. Substitution saturation was evaluated with DAMBE 5 [23]. Phylogenetic analyses were conducted with RAxML v8.2.9 (maximum likelihood analysis; [24]) and Mr. Bayes 3. 2.6 (Bayesian inference; [25]), employing the GTR+I+G model calculated by Jmodeltest2 [26] using the Akaike Information Criterion (AIC). For maximum likelihood analysis, 1000 bootstrap pseudoreplicates were performed. For Bayesian inference, 3,000,000 generations of Markov chain Monte Carlo simulations were run. For every 100 generations, tree-sampling was conducted and the initial 7500 trees were taken out as 'burn-in'. Chain convergence was examined with Tracer v1.6 [27]. Distance estimation was carried out between nine closely related sequences, using the $\mathrm{p}$-distance model of substitution in FastME 2.0 [28]. The alignments were trimmed so as to eliminate nucleotide positions with gaps, resulting in a final data set of 796 characters. Visualization of the genetic distance matrix was generated using a custom Python script.

\section{Results}

Parasitological examination revealed that numerous whitish and ellipsoidal plasmodia measuring up to $\sim 660$ $\mu \mathrm{m}$ were located in the gill lamellae of infected common carp specimens (Fig. 1). After rupturing the plasmodia, mature spores with two unequal polar capsules, one of which is extremely stunted, were observed, thus defining classification within the genus Myxobolus.

\section{Family Myxobolidae Thélohan, 1892 Genus Myxobolus Bütschli, 1882}

Myxobolus pseudoacinosus nom. nov.

Syn. Myxobolus paratoyamai Kato, Kasai, Tomochi, Li \& Sato, 2017 nec Myxobolus paratoyamai Nie \& Li, 1992

Host: Cyprinus carpio L. (Cypriniformes: Cyprinidae), common carp.

Locality: Baishazhou Fish Market $\left(30^{\circ} 28^{\prime} 47^{\prime \prime} \mathrm{N}, 114^{\circ}\right.$ 21'20"E), Wuhan, China.

Site in host: Gills.

Voucher material: Giemsa-stained slides with mature spores of M. pseudoacinosus were deposited in the $\mathrm{Na}$ tional Zoological Museum of China, Institute of
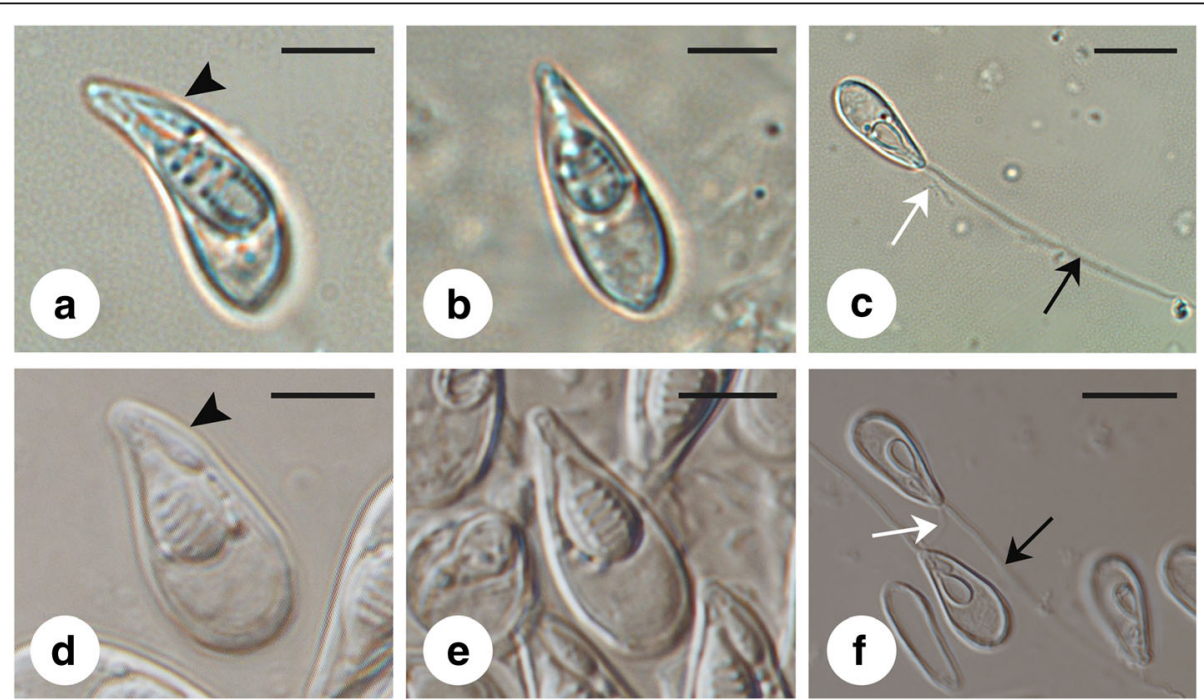

Fig. 2 Fresh spores of Myxobolus pseudoacinosus. a-c The narrow type. d-f The wide type. a, $\mathbf{d}$ Spore in frontal view. Note the stunted polar capsule (arrowhead). b, e Spore in sutural view. c, f Spore with polar filaments extruded. The white and black arrows indicate the short and long polar filaments from the small polar capsule and large polar capsule, respectively. Scale-bars: a, b, d, e, $5 \mu \mathrm{m}$; c, f, $10 \mu \mathrm{m}$ 

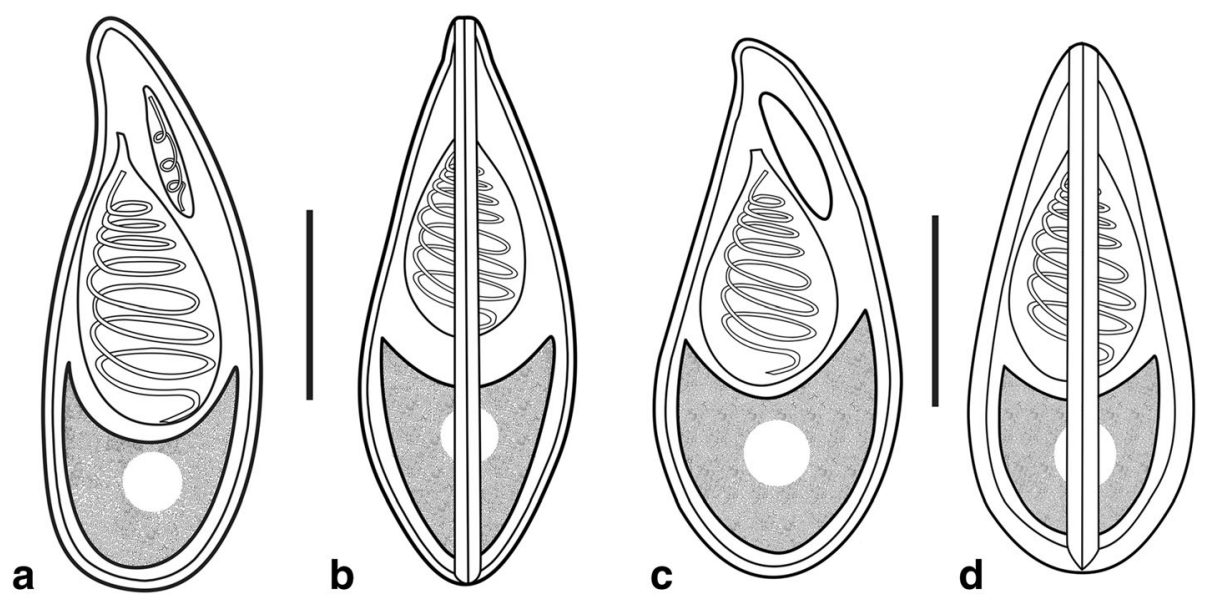

Fig. 3 Schematic drawing of mature spores of Myxobolus pseudoacinosus. a, b The narrow type. c, d The wide type. a, c Frontal view. b, d Sutural view. Scale-bars: $5 \mu \mathrm{m}$

Zoology, Chinese Academy of Sciences (IZCAS) under the accession numbers MTR20150428 (narrow type) and MTR20130121 (wide type).

Prevalence: 25\% (1/4) in 2015 specimen; 2.9\% (1/34) in 2013 specimen.

Representative DNA sequences: GenBank accession numbers: KX586684 (narrow type); KX810019, KX810020 (wide type).
ZooBank registration: To comply with the regulations set out in article 8.5 of the amended 2012 version of the International Code of Zoological Nomenclature (ICZN) [29], details of Myxobolus pseudoacinosus have been submitted to ZooBank. The Life Science Identifier (LSID) for the article is urn:lsid:zoobank.org:act:442CC572-59E4-448B-8370FCC2ACEACB70.

Table 1 Comparative measurements (in $\mu \mathrm{m}$ ) shown as range (mean \pm SD) of Myxobolus pseudoacinosus and morphologically similar Myxobolus spp. from Cyprinus carpio

\begin{tabular}{|c|c|c|c|c|c|c|c|c|c|c|c|}
\hline Species & Country & $\begin{array}{l}\text { Infection } \\
\text { site }\end{array}$ & LS & WS & TS & LLPC & WLPC & LSPC & WSPC & NCF & Reference \\
\hline $\begin{array}{l}\text { Narrow } \\
\text { type }\end{array}$ & China & Gills & $\begin{array}{l}14.3-15.9 \\
(15.0 \pm 0.5)\end{array}$ & $\begin{array}{l}4.3-6.6 \\
(5.5 \pm 0.5)\end{array}$ & $\begin{array}{l}4.4-6.2 \\
(5.0 \pm 0.3)\end{array}$ & $\begin{array}{l}5.7-7.8 \\
(6.6 \pm 0.5)\end{array}$ & $\begin{array}{l}2.2-3.9 \\
(2.9 \pm 0.4)\end{array}$ & $\begin{array}{l}3.0-4.3 \\
(3.6 \pm 0.3)\end{array}$ & $\begin{array}{l}0.6-1.6 \\
(1.0 \pm 0.2)\end{array}$ & $7-8$ & Present study \\
\hline Wide type & China & Gills & $\begin{array}{l}12.9-15.6 \\
(14.1 \pm 0.5)\end{array}$ & $\begin{array}{l}6.0-7.3 \\
(6.5 \pm 0.3)\end{array}$ & $5.2-5.8$ & $\begin{array}{l}6.0-7.3 \\
(6.5 \pm 0.3)\end{array}$ & $\begin{array}{l}3.2-4.2 \\
(3.7 \pm 0.2)\end{array}$ & $\begin{array}{l}2.8-3.8 \\
(3.2 \pm 0.3)\end{array}$ & $\begin{array}{l}0.9-1.4 \\
(1.2 \pm 0.1)\end{array}$ & $6-8$ & Present study \\
\hline $\begin{array}{l}\text { M. } \\
\text { paratoyamai }\end{array}$ & Japan & Gills & $\begin{array}{l}14.7-16.4 \\
(15.4)\end{array}$ & $\begin{array}{l}5.5-6.8 \\
(6.3)\end{array}$ & $\begin{array}{l}5.6-6.4 \\
(6.1)\end{array}$ & $\begin{array}{l}5.9-7.1 \\
(6.5)\end{array}$ & $\begin{array}{l}3.1-4.2 \\
(3.7)\end{array}$ & - & - & $5-6$ & [12] \\
\hline $\begin{array}{l}\text { M. } \\
\text { paratoyamai }\end{array}$ & China & $\begin{array}{l}\text { Nares, } \\
\text { ureter }\end{array}$ & $12.5-14.2$ & $5.5-7.0$ & 5.0 & $6.2-7.4$ & $2.2-2.5$ & - & - & - & [2] \\
\hline M. acinosus & China & Gills & $\begin{array}{l}10.8-13.2 \\
(12.6)\end{array}$ & $\begin{array}{l}5.6-7.2 \\
(6.4)\end{array}$ & $\begin{array}{l}4.8-6.0 \\
(5.3)\end{array}$ & $\begin{array}{l}4.8-6.0 \\
(5.3)\end{array}$ & $\begin{array}{l}2.4-3.4 \\
(2.8)\end{array}$ & $2.4-3.0$ & $1.0-1.4$ & $5-6$ & [2] \\
\hline M. acinosus & China & Gills & $\begin{array}{l}10.1-11.3 \\
(10.7 \pm 0.4)\end{array}$ & $\begin{array}{l}5.5-6.7 \\
(5.9 \pm 0.3)\end{array}$ & - & $\begin{array}{l}4.3-5.4 \\
(4.9 \pm 0.3)\end{array}$ & $\begin{array}{l}2.7-3.3 \\
(3.0 \pm 0.2)\end{array}$ & $\begin{array}{l}2.6-3.3 \\
(3.0 \pm 0.3)\end{array}$ & $\begin{array}{l}1.0-1.5 \\
(1.3 \pm 0.2)\end{array}$ & $7-8$ & $\begin{array}{l}\text { Huang \& Gu } \\
\text { (unpublished) }\end{array}$ \\
\hline M. toyamai & Japan & Gills & 15.0 & $7.0-8.0$ & - & $7.0-8.0$ & $3.0-4.0$ & - & - & - & [38] \\
\hline M. toyamai & China & $\begin{array}{l}\text { Gills, } \\
\text { kidneys }\end{array}$ & $\begin{array}{l}13.2-15.6 \\
(14.0)\end{array}$ & $\begin{array}{l}4.8-6.0 \\
(5.5)\end{array}$ & $4.4-5.4$ & 5.7 & $2.4-3.6$ & $2.4-3.6$ & $0.6-1.0$ & $7-8$ & [2] \\
\hline M. toyamai & USA & Gills & $\begin{array}{l}14.7-16.8 \\
(16.2)\end{array}$ & $\begin{array}{l}4.5-6.0 \\
(5.6)\end{array}$ & - & $\begin{array}{l}5.8-7.2 \\
(6.4)\end{array}$ & $\begin{array}{l}3.4-4.6 \\
(4.2)\end{array}$ & - & - & - & [31] \\
\hline M. toyamai & Japan & Gills & $\begin{array}{l}13.5-15.8 \\
(14.3)\end{array}$ & $\begin{array}{l}4.5-6.3 \\
(5.5)\end{array}$ & - & $\begin{array}{l}5.0-6.8 \\
(5.8)\end{array}$ & $\begin{array}{l}2.3-4.5 \\
(3.5)\end{array}$ & $\begin{array}{l}2.7-4.5 \\
(3.4)\end{array}$ & $\begin{array}{l}0.5-1.4 \\
(0.8)\end{array}$ & - & [39] \\
\hline
\end{tabular}

Abbreviations: LS, spore length; WS, spore width; TS, spore thickness; LLPC, large polar capsule length; WLPC, large polar capsule width; LSPC, small polar capsule length; WSPC, small polar capsule width; NCF, number of polar filament coils; -, not available 

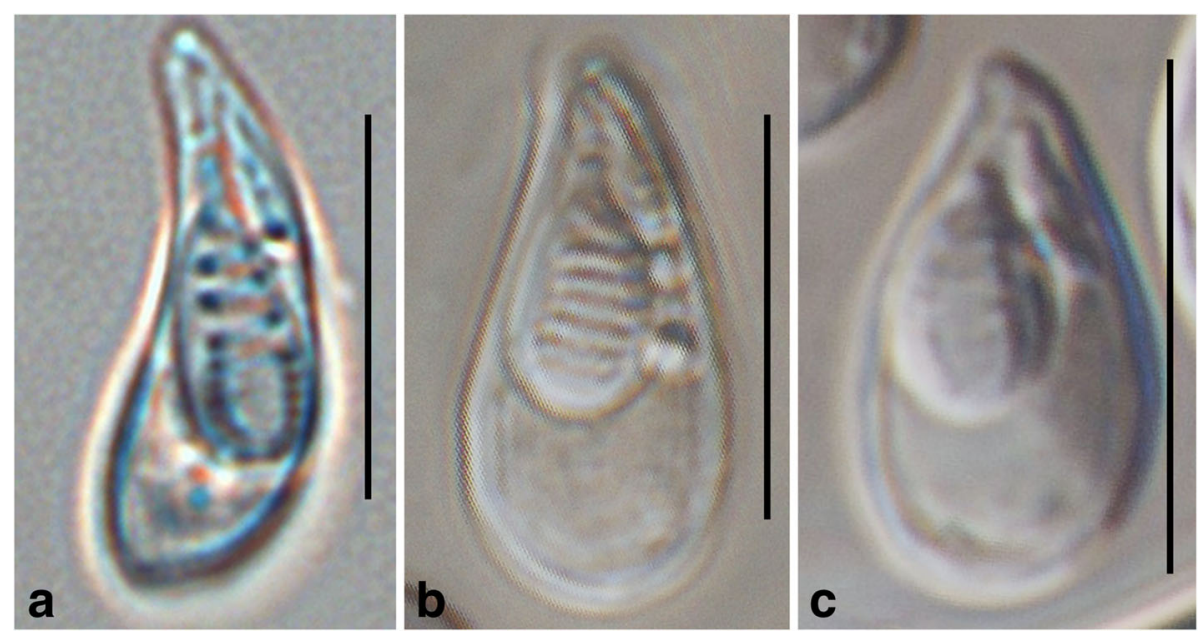

Fig. 4 Mature spores of Myxobolus pseudoacinosus and Myxobolus acinosus Nie \& Li, 1973. a M. pseudoacinosus narrow type. b M. pseudoacinosus wide type. c M. acinosus (unpublished data by Huang \& Gu). Scale-bars: $10 \mu \mathrm{m}$

Etymology: The species is named after its morphological similarity to Myxobolus acinosus Nie \& Li, 1973.

\section{Description}

Mature spores eggplant shaped in the valvular view, protruding anteriorly, bluntly rounded posteriorly; in sutural view, spores pear-shaped, pointing and curving anteriorly. Extrusion of both short and long polar filaments obvious (Fig. 2c, f). Narrow-type spores (Figs. 2a-c, 3a, b) measuring
$14.3-15.9(15.0 \pm 0.5) \times 4.3-6.6(5.5 \pm 0.5) \times 4.4-6.2(5.0 \pm$ $0.3)$; large polar capsule 5.7-7.8 $(6.6 \pm 0.5) \times 2.2-3.9(2.9 \pm$ $0.4)$; small polar capsule 3.0-4.3 (3.6 \pm 0.3$) \times 0.6-1.6(1.0 \pm$ 0.2). Polar filaments inside large polar capsule with 7-8 turns; polar filament of stunted polar capsule with 2-3 turns. Wide-type spores (Figs. $2 \mathrm{~d}$-f, 3c, d) measuring 12.9$15.6(14.1 \pm 0.5) \times 6.0-7.3(6.5 \pm 0.3) \times 5.2-5.8$; large polar capsule 6.0-7.3 $(6.5 \pm 0.3) \times 3.2-4.2(3.7 \pm 0.2)$; small polar capsule $2.8-3.8(3.2 \pm 0.3) \times 0.9-1.4(1.2 \pm 0.1)$.

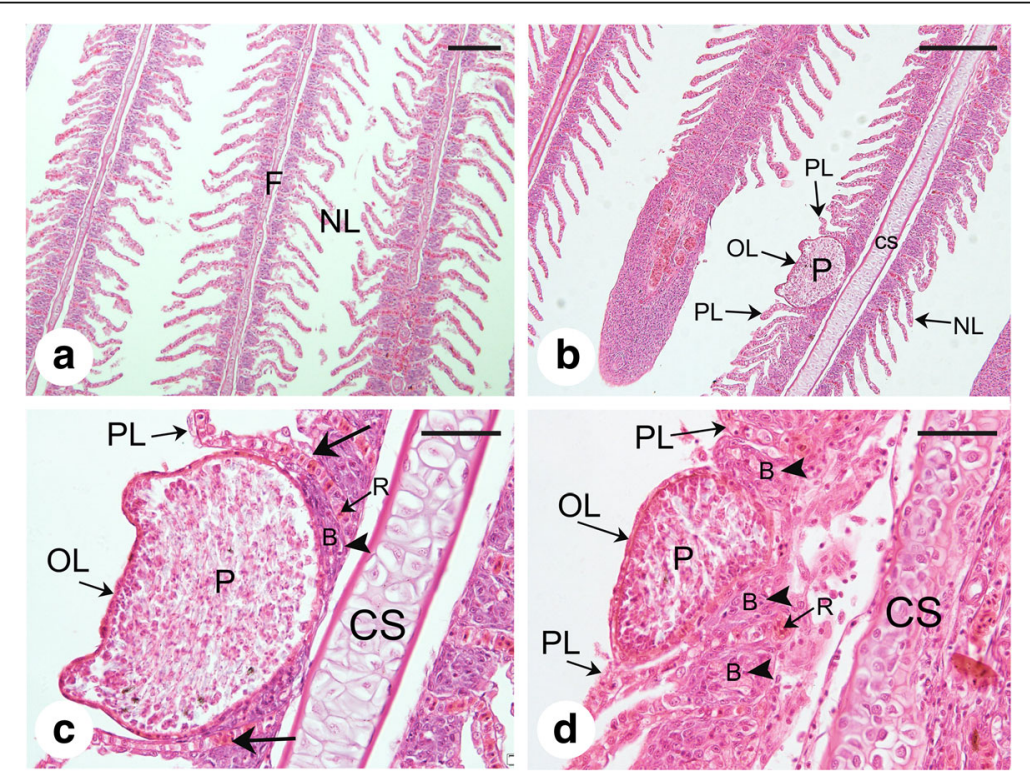

Fig. 5 Histological sections of gills of the common carp Cyprinus carpio infected by Myxobolus pseudoacinosus (narrow type). a Normal uninfected gill tissue with parallel filaments and intact gill lamellae. b Plasmodia of M. pseudoacinosus developing in the lumen of lamellar capillaries. c, d Higher magnification showing plasmodia located within the lumen of lamellar capillaries, pushing aside neighbouring lamellae (large arrows) and compressing the undifferentiated basal cells (arrowhead). The cartilaginous structure remains intact. Abbreviations: B, undifferentiated basal cells; CS, cartilaginous structure; F, gill filaments; NL, normal gill lamellae; OL, plasmodia-occupied gill lamellae; P, plasmodia; PL, gill lamellae become pushed aside; R, red blood cells. Scale-bars: $\mathbf{a}, \mathbf{b}, 200 \mu \mathrm{m} ; \mathbf{c}, \mathbf{d}, 50 \mu \mathrm{m}$ 


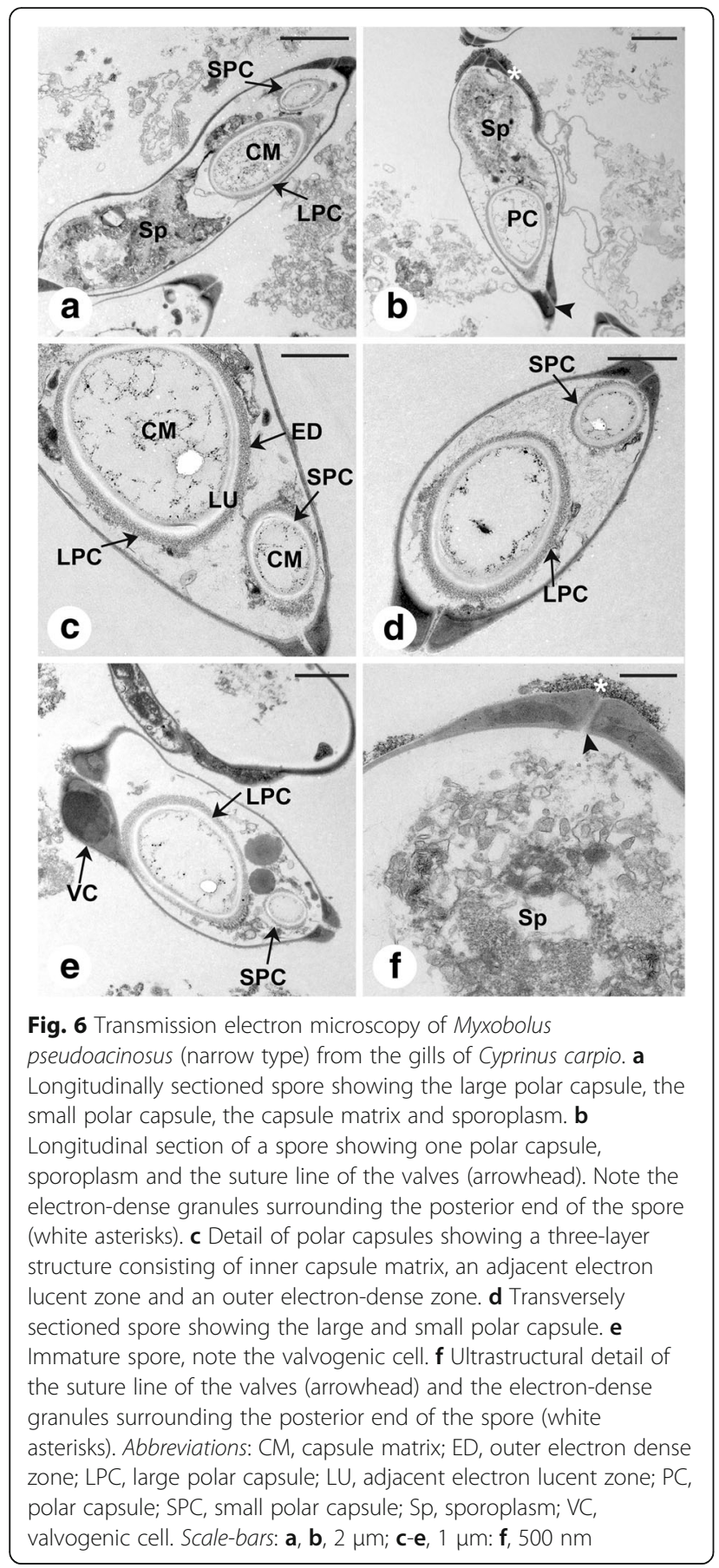

\section{Remarks}

Although lacking molecular data, M. paratoyamai Nie \& Li, 1992 clearly shows different morphology (shorter spore length, smaller and more posterior small polar capsule) and infection sites (nares, ureter) from the present species. Myxobolus acinosus Nie \& Li, 1973 can be readily distinguished from both narrow type and wide type by its much shorter spore shape and shorter large polar capsule. Notably, while $M$. toyamai and the wide type clearly differ in spore width, it is hard to discriminate $M$. paratoyamai Kato, Kasai, Tomochi, Li \& Sato, 2017 from the wide type based solely on morphology because they have highly similar morphology parameters. Similarly, M. toyamai and the narrow type also could not be morphologically distinguished. Details of above comparative metrical data and images of the present species and $M$. acinosus are presented in Table 1 and Fig. 4. The original images of $M$. acinosus, M. paratoyamai Nie \& Li, 1992 and M. toyamai of Griffin \& Goodwin, 2011 can be accessed in [2, 30, 31] respectively.

\section{Histopathological examination}

Histological analysis showed that plasmodia developed in the lumen of lamellar capillaries (Fig. 5b). Compared to the normal gill tissue (Fig. 5a), the gill lamellae neighboring the plasmodia were pushed aside, and the undifferentiated basal cells were compressed (Fig. 5c, d). However, the rest of the gill lamellae and the cartilaginous structure remained intact. No inflammatory responses, including swelling or inflammatory cell infiltrations, were found in any of the histological slides examined.

\section{Ultrastructure}

The presence of a second stunted polar capsule was confirmed by the ultrastructural results (Fig. 6d). Two symmetrical valves, which were joined by a sutural ridge, surrounded the two unequal- sized pyriform polar capsules (Fig. 6a). The polar capsules showed a three-layer structure that consisted of an inner capsule matrix, an adjacent electron-lucent zone and an outer electron-dense zone (Fig. 6c). Numerous sporoplasmosomes and a few vacuoles were observed in the sporoplasm, which was located in the posterior end of myxospore (Fig. 6a, b, f). The distal end of the spore was surrounded by electron-dense granules (Fig. 6b, f). The valvogenic cell could be observed in immature spores (Fig. 6e).

\section{Molecular analysis}

Molecularly, the SSU rDNA sequences obtained from narrow-type and wide-type spores shared high identity (KX586684 vs KX810019: 99.6\%, identities 1312/1317 bp; KX586684 vs KX810020: 99.8\%, identities 1042/1044 bp). Blast searches based on the 2025 bases of the SSU rDNA sequence (KX586684) showed almost identical values to M. paratoyamai Kato, Kasai, Tomochi, Li \& Sato, 2017 (LC228237: 99.3\%, identities 1991/2006 bp), and revealed a close relationship between the species of interest and $M$. acinosus (KX810021: 98.6\%, identities 1299/1318 bp; KX810022: 98.8\%, identities 1933/1957 bp; KX810023: 98.7\%, identities 1030/1044 bp), 
Table 2 Genetic distances (bellow the diagonal) and sequence similarities (in \%, above the diagonal) of Myxobolus pseudoacinosus and closely related Myxobolus spp. based on SSU rDNA sequence data

\begin{tabular}{|c|c|c|c|c|c|c|c|c|c|c|c|}
\hline & Species (GenBank ID) & 1 & 2 & 3 & 4 & 5 & 6 & 7 & 8 & 9 & 10 \\
\hline 1 & Narrow type (KX586684) & & 99.6 & 99.8 & 99.3 & 98.6 & 98.8 & 97.5 & 97.4 & 97.2 & 98.7 \\
\hline 2 & Wide type (KX810019) & 0.004 & & 99.5 & 98.9 & 98.5 & 98.5 & 96.4 & 96.4 & 96.4 & 98.2 \\
\hline 3 & Wide type (KX810020) & 0.005 & 0.009 & & 99.5 & 98.6 & 98.8 & 97.0 & 97.1 & 97.1 & 98.8 \\
\hline 4 & M. paratoyamai (LC228237) & 0.003 & 0.006 & 0.008 & & 98.3 & 98.6 & 97.7 & 97.7 & 97.5 & 98.6 \\
\hline 5 & M. acinosus (KX810021) & 0.013 & 0.016 & 0.018 & 0.015 & & 100 & 96.1 & 96.2 & 96.2 & 97.8 \\
\hline 6 & M. acinosus (KX810022) & 0.013 & 0.016 & 0.018 & 0.015 & 0.000 & & 97.1 & 97.1 & 97.1 & 98.2 \\
\hline 7 & M. toyamai (LC010115) & 0.034 & 0.038 & 0.039 & 0.034 & 0.041 & 0.041 & & 99.8 & 99.5 & 97.4 \\
\hline 8 & M. toyamai (FJ710802) & 0.033 & 0.036 & 0.038 & 0.033 & 0.040 & 0.040 & 0.001 & & 99.8 & 97.3 \\
\hline 9 & M. toyamai (HQ338729) & 0.033 & 0.036 & 0.038 & 0.033 & 0.040 & 0.040 & 0.001 & 0.000 & & 97.1 \\
\hline 10 & M. longisporus (AY364637) & 0.010 & 0.014 & 0.015 & 0.010 & 0.020 & 0.020 & 0.031 & 0.030 & 0.030 & \\
\hline
\end{tabular}

Myxobolus longisporus Nie \& Li, 1992 (AY36463: 98.7\%, identities $2003 / 2029 \mathrm{bp}$ ), followed by $M$. toyamai (LC010116: 97.6\%, identities 1951/2000 bp; LC010115: 97.5\%, identities 1949/2000 bp; HQ338729: 97.2\%, identities 1912/1967 bp).

Results of evolutionary divergence over SSU rDNA sequence pairs between the present species and the closely related Myxobolus species are listed in Table 2 and visualized in Fig. 7b. The p-distance values for the present species compared with M. longisporus (0.010), $M$. acinosus (0.013), M. toyamai (0.033-0.034) are far greater than the intraspecific p-distance of $M$. pseudoacinosus (0.003-0.005) and M. toyamai (0-0.001).

Phylogenetic analysis revealed that the present species was positioned within the well-supported Myxobolus gill-infecting subclade and clustered with several

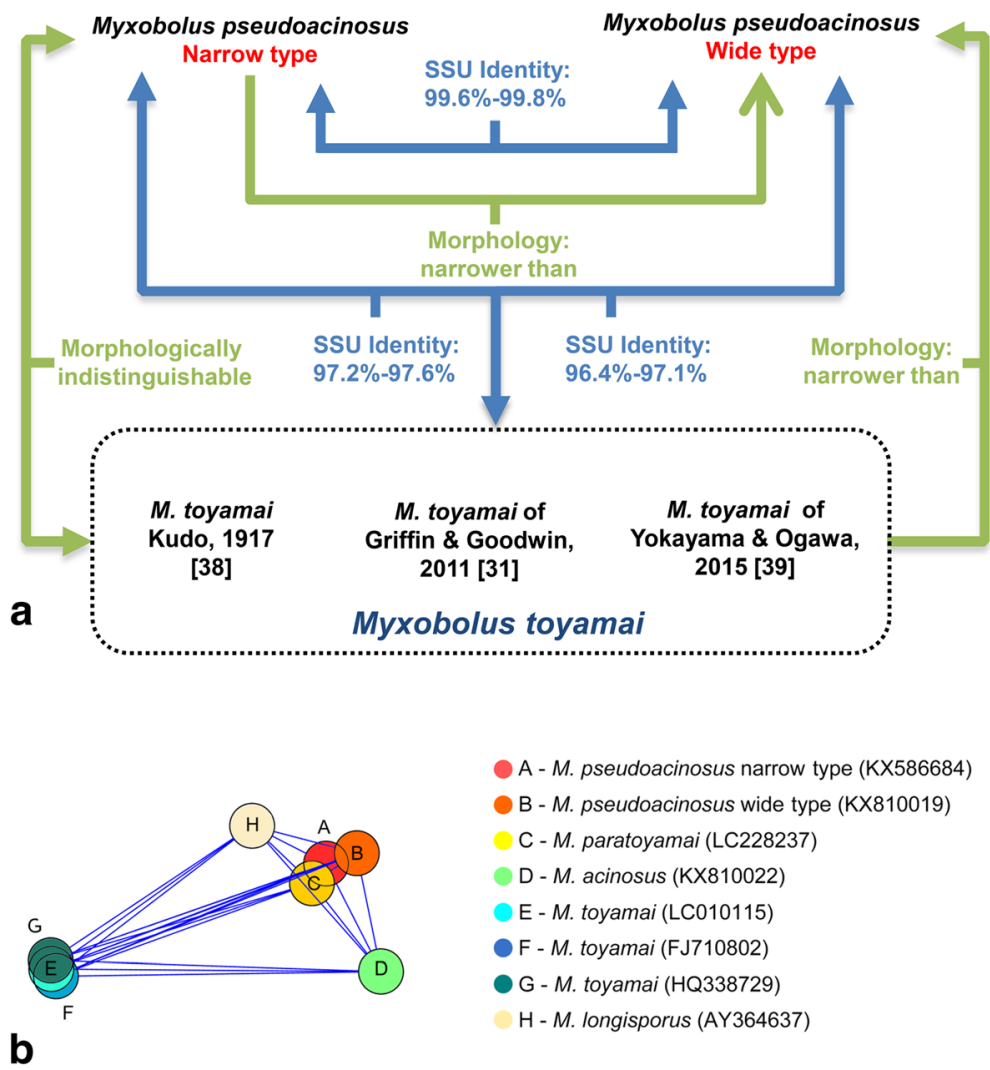

Fig. 7 Species validity assessment of Myxobolus pseudoacinosus. a Schematic diagram showing the general situation of the present study. b Visualization of the genetic distance matrix between the SSU rDNA sequence pairs of M. pseudoacinosus and closely related species (see Table 2 for details) 


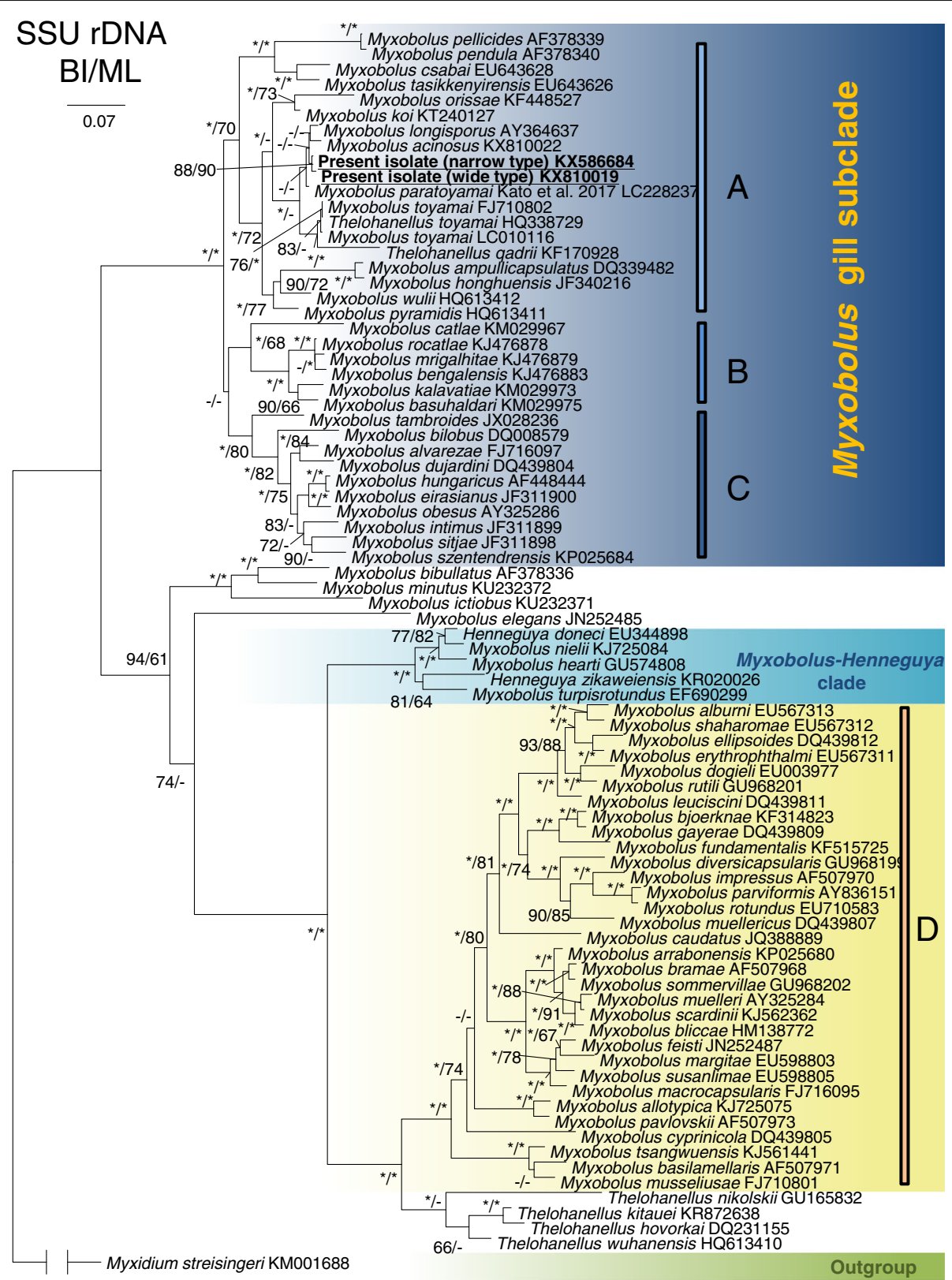

Fig. 8 SSU rDNA phylogeny of Myxobolus pseudoacinosus and other selected myxozoan species obtained by Bayesian inference analysis. Numbers at branching nodes are Bayesian posterior probabilities/bootstrap values of maximum likelihood analysis (in \%). Asterisks represent values $\geq 95 \%$. Dashes represent values $\leq 60 \%$ or alternative maximum likelihood topology

myxozoans that exclusively parasitize the gill of cyprinid fish: M. longisporus (AY36463); M. acinosus (KX810022); M. toyamai (LC010116, HQ338729, FJ710802); and Thelohanellus qadrii (KF170928) (Fig. 8).

\section{Discussion}

To facilitate species identification, the spores collected from the gills of common carp in 2013 and 2015 were studied using a holistic approach comprising spore morphology, biological traits and DNA data. Morphologically, the spores collected in 2013 possessed obviously wider spores and wider large polar capsules than those collected in 2015. Molecular analysis revealed that the two myxozoan samples share almost identical SSU rDNA sequences (99.6-99.8\%). Considering the fact that intraspecific morphometric variation [11] and morphotypes [10,32] are common in myxozoans, the two samples from the gills of common carp were considered to be conspecific with each representing a morphotype of the same species, i.e. wide type (spores collected in 2013) and narrow type (spores collected in 2015). 
A holistic comparison between spores of these two morphotypes and the related Myxobolus spp. infecting the common carp was also undertaken. The wide-type spores show high similarity with a recently described species $M$. paratoyamai Kato, Kasai, Tomochi, Li \& Sato, 2017 [12] in morphology, biological traits and SSU rDNA. Thus, the wide-type morph and M. paratoyamai Kato, Kasai, Tomochi, Li \& Sato, 2017 were confidently considered to be the same species.

Interestingly, the narrow-type spores showed highly similar morphology to M. toyamai and molecular comparison revealed $2.4-2.8 \%$ differences in SSU rDNA sequences (KX586684 vs LC010116: 97.6\%; KX586684 vs LC010115: 97.5\%; KX586684 vs HQ338729: 97.2\%). According to previous research [33], intraspecific SSU rDNA differences for myxozoans typically range from $0-3.6 \%$ and can even be as high as 5\% in the case of Myxobolus pseudodispar Gorbunova, 1936 [34]. The 2.4-2.8\% SSU rDNA differences between the narrow-type spores and $M$. toyamai were thus not enough to designate them as different species. However, based on the classification system of Molnár [35], the infection site of narrow-type spores (intralamellar-vascular, LV3) (Additional file 1: Figure S1) and $M$. toyamai (intrafilamental-epithelial, FE) are different [31]. Despite the totally different tissue-specificity between the narrow-type spores and $M$. toyamai, there have been cases in which one myxozoan species was found to infect multiple tissues/organs $[34,36]$. Taken together, these data do not allow narrow-type spores and M. toyamai to be easily distinguished and their relationship needs further investigation.

In order to resolve the taxonomic dilemma encountered here, a hypothesis was proposed: narrow-type spores and $M$. toyamai are conspecific. Based on this hypothesis, $M$. toyamai would be designated as a species with intraspecific SSU rDNA divergence of 3.6\%. However, this can give rise to new problems in explaining the fact that SSU rDNA sequence of the present species is more similar to that of $M$. paratoyamai, M. acinosus (a valid species morphologically distinct from $M$. toyamai, see [2]) and $M$. longisporus (a valid species morphologically distinct from M. toyamai, see [37]) than to M. toyamai itself (Fig. 7b). Correspondingly, it will also be inappropriate and illogical to put M. paratoyamai Kato, Kasai, Tomochi, Li \& Sato, 2017, M. acinosus and M. longisporus along with the present species in the M. toyamai "complex" and designate three new morphotypes. Thus, the hypothesis about the conspecificity of the narrow type and $M$. toyamai is not supported by the data presented here.

Based on the data presented above, the species described in this work is herein designated as M. paratoyamai Kato, Kasai, Tomochi, Li \& Sato, 2017, but with two morphotypes [12]. Considering that this species name was preoccupied by Myxobolus paratoyamai Nie \& Li, 1992
[2, 30], the replacement name Myxobolus pseudoacinosus nom. nov. is proposed. Although lacking molecular data, M. paratoyamai $\mathrm{Nie} \& \mathrm{Li}, 1992$ can be easily distinguished from the present species.

\section{Conclusions}

In conclusion, this study addressed the taxonomic dilemma phenomenon, using $M$. pseudoacinosus as a case study. The key considerations to bear in mind when dealing with future taxonomic dilemmas are: (i) intraspecific morphometric variation and morphotypes do exist among myxozoan populations; and (ii) at least for Myxobolus species, the co-occurrence of indistinguishable spore morphology and a SSU rDNA difference as low as $2.4 \%$ does not necessarily define conspecificity. Moreover, this study is not without limitations. One improvement that can be made is to obtain extra histological and ultrastructural data from wide-type spores, thus making it possible to more thoroughly compare the two morphotypes. Another improvement involves a broader sampling of host specimens, which would enable us to enlarge extensively the view of the myxozoan genetic and morphologic variability. Future work will focus on improving our understanding of the biology of this species and of the variant characteristics of Myxobolus species more broadly.

\section{Additional file}

Additional file 1: Figure S1. The intralamellar vascular site preference of M. pseudoacinosus in gills. a The plasmodia of M. pseudoacinosus developed in the lumen of lamellar capillaries. The area highlighted in blue represents the gill lamellae. $\mathbf{b}$ The site preference type of $M$. pseudoacinosus met the definition of intralamellar vascular type 3 (LV3) from the classification system of Molnár [35]. Abbreviations: P, plasmodia; LV, intralamellar vascular. (TIF $4655 \mathrm{~kb}$ )

Abbreviations

AIC: Akaike information criterion; FE: Intrafilamental-epithelial; LV3: Intralamellar-vascular; SD: Standard deviation; SSU rDNA: Small subunit ribosomal deoxyribonucleic acid

\section{Acknowledgements}

We acknowledge funding from Nature Science Foundation of China (31572233), China Agriculture Research System (CARS-46), the Hubei Agricultural Science and Technology Innovation Center (2016620000001046), Featuring Talents Cultivation Project (4611300108).

\section{Funding}

The present work was funded by Nature Science Foundation of China (31572233), China Agriculture Research System (CARS-46), the Hubei Agricultural Science and Technology Innovation Center (2016620000001046), Featuring Talents Cultivation Project (4611300108).

\section{Availability of data and materials}

The data supporting the conclusions of this article are included within the article. The SSU rDNA sequences for Myxobolus pseudoacinosus were deposited to the GenBank database under the accession numbers KX586684, KX810019 and KX810020. Voucher material for M. pseudoacinosus was deposited in National Zoological Museum of China, Institute of Zoology, 
Chinese Academy of Sciences (IZCAS) under the accession number MTR20150428 (narrow type) and MTR20130121 (wide type).

\section{Authors' contributions}

QXG analyzed the results and drafted the manuscripts. QXG, YL and ZMG conceived and designed the study. QXG, MJH and XPZ were responsible for the field studies. QXG and MJH performed the laboratory work. QXG, MJH, $Y L, X P Z$ and ZMG edited and finalized the manuscript. All authors read and approved the final manuscript.

\section{Ethics approval and consent to participate}

All animal care protocols complied with the guidelines established by the National Institutes of Health and the International Society for Development Psychobiology (Guide for the care and use of laboratory animals, P 77, Aquatic Animals, National Research Council, 2010).

\section{Consent for publication}

Not applicable.

\section{Competing interests}

The authors declare that they have no competing interests.

\section{Publisher's Note}

Springer Nature remains neutral with regard to jurisdictional claims in published maps and institutional affiliations.

Received: 2 January 2018 Accepted: 7 June 2018

Published online: 09 July 2018

\section{References}

1. Lom J, Dyková I. Myxozoan genera: definition and notes on taxonomy, lifecycle terminology and pathogenic species. Folia Parasitol (Praha). 2006;53:1.

2. Chen $\mathrm{QL}, \mathrm{Ma} \mathrm{CL}$. Myxozoa, Myxosporea: a major project of the National Natural Science Foundation of China. Beijing: Science Press; 1998.

3. Molnár K, Székely C, Hallett SL, Atkinson SD. Some remarks on the occurrence, host-specificity and validity of Myxobolus rotundus Nemeczek, 1911 (Myxozoa: Myxosporea). Syst Parasitol. 2009;72:71-9.

4. Okamura B, Gruhl A, Bartholomew JL, editors. Myxozoan evolution, ecology and development. Cham: Springer International Publishing; 2015.

5. Liu Y, Zhai Y, Gu Z. Morphological and molecular characterization of Thelohanellus macrovacuolaris n. sp. (Myxosporea: Bivalvulida) infecting the palate in the mouth of common carp Cyprinus carpio L. in China. Parasitol Int. 2016;65:303-7.

6. Székely C, Cech G, Atkinson SD, Molnár K, Egyed L, Gubányi A. A nove myxozoan parasite of terrestrial mammals: description of Soricimyxum minuti sp. n. (Myxosporea) in pygmy shrew Sorex minutus from Hungary. Folia Parasitol (Praha). 2015;62:1-5.

7. Liu XH, Batueva MD, Zhao YL, Zhang JY, Zhang QQ, Li TT, et al. Morphological and molecular characterisation of Myxobolus pronini $\mathrm{n}$. sp. (Myxozoa: Myxobolidae) from the abdominal cavity and visceral serous membranes of the gibel carp Carassius auratus gibelio (Bloch) in Russia and China. Parasit Vectors. 2016:9:562

8. Liu Y, Gu ZM, Luo YL. Some additional data to the occurrence, morphology and validity of Myxobolus turpisrotundus Zhang, 2009 (Myxozoa: Myxosporea). Parasitol Res. 2010;107:67-73.

9. Zhang JY, Wang JG, Li AH, Gong XN. Infection of Myxobolus turpisrotundus sp. n. in allogynogenetic gibel carp, Carassius auratus gibelio (Bloch), with revision of Myxobolus rotundus (s. I.) Nemeczek reported from C. auratus auratus (L.): Myxobolus turpisrotundus sp. n. from gibel carp. J Fish Dis. 2010; 33:625-38.

10. Camus AC, Griffin MJ. Molecular characterization and histopathology of Myxobolus koi infecting the gills of a koi, Cyprinus carpio, with an amended morphological description of the agent. J Parasitol. 2010;96:116-24.

11. Zhai Y, Whipps CM, Gu Z, Guo Q, Wu Z, Wang H, Liu Y. Intraspecific morphometric variation in myxosporeans. Folia Parasitol (Praha). 2015;63:011.

12. Kato E, Kasai A, Tomochi H, Li Y-C, Sato H. Four Myxobolus spp. (Myxosporea: Bivalvulida) from the gill lamellae of common carp (Cyprinus carpio) and Japanese silver crucian carp (Carassius langsdorfii) in the western part of Japan, with the description of three new species (M. tanakai n. sp., M. paratoyamai n. sp., and M. ginbuna n. sp.). Parasitol Res. 2017;116:2427-41.
13. Lom J, Arthur JR. A guideline for the preparation of species descriptions in Myxosporea. J Fish Dis. 1989;12:151-6.

14. Liu Y, Yuan J, Jia L, Huang M, Zhou Z, Gu Z. Supplemental description of Thelohanellus wuhanensis Xiao \& Chen, 1993 (Myxozoa: Myxosporea) infecting the skin of Carassius auratus gibelio (Bloch): ultrastructural and histological data. Parasitol Int. 2014;63:489-91.

15. Hillis DM, Dixon MT. Ribosomal DNA: molecular evolution and phylogenetic inference. Q Rev Biol. 1991;66:411-53.

16. Whipps CM, Adlard RD, Bryant MS, Lester RJ, FINDLAV V, Kent ML. First report of three Kudoa species from eastern Australia: Kudoa thyrsites from mahi mahi (Coryphaena hippurus), Kudoa amamiensis and Kudoa minithyrsites n. sp. from sweeper (Pempheris ypsilychnus). J Eukaryot Microbiol. 2003:50:215-9.

17. Fiala I. The phylogeny of Myxosporea (Myxozoa) based on small subunit ribosomal RNA gene analysis. Int J Parasitol. 2006:36:1521-34.

18. Eszterbauer E, Székely C. Molecular phylogeny of the kidney-parasitic Sphaerospora renicola from common carp (Cyprinus carpio) and Sphaerospora sp. from goldfish (Carassius auratus auratus). Acta Vet Hung. 2004;52:469-78.

19. Zhao D, Borkhanuddin MH, Wang W, Liu Y, Cech G, Zhai Y, Székely C. The life cycle of Thelohanellus kitauei (Myxozoa: Myxosporea) infecting common carp (Cyprinus carpio) involves aurantiactinomyxon in Branchiura sowerbyi. Parasitol Res. 2016;115:4317-25.

20. Hall TA. BioEdit: a user-friendly biological sequence alignment editor and analysis program for Windows 95/98/NT. Nucleic Acids Symp Ser. 1999;41:95-8.

21. Katoh K, Standley DM. MAFFT: multiple sequence alignment software version 7: improvements in performance and usability. Mol Biol Evol. 2013;30:772-80,

22. Castresana J. Selection of conserved blocks from multiple alignments for their use in phylogenetic analysis. Mol Biol Evol. 2000;17:540-52.

23. Xia X. DAMBE5: a comprehensive software package for data analysis in molecular biology and evolution. Mol Biol Evol. 2013;30:1720-8.

24. Stamatakis A. RAXML version 8: a tool for phylogenetic analysis and postanalysis of large phylogenies. BOINFP. 2014;30:1312-3.

25. Ronquist F, Teslenko M, van der Mark P, Ayres DL, Darling A, Höhna S, et al. MrBayes 3.2: efficient Bayesian phylogenetic inference and model choice across a large model space. Syst Biol. 2012;61:539-42.

26. Darriba D, Taboada GL, Doallo R, Posada D. jModelTest 2: more models, new heuristics and parallel computing. Nat Methods. 2012;9:772.

27. Rambaut A, Suchard MA, Xie D, Drummond AJ. Tracer v1.6. 2014. http://tree bio.ed.ac.uk/software/tracer/.

28. Lefort V, Desper R, Gascuel O. FastME 2.0: a comprehensive, accurate, and fast distance-based phylogeny inference program. Mol Biol Evol. 2015;32:2798-800.

29. ICZN. International Commission on Zoological Nomenclature: Amendment of articles 8, 9, 10, 21 and 78 of the International Code of Zoological Nomenclature to expand and refine methods of publication. Bull Zool Nomencl. 2012;69:161-9.

30. Nie D, Li L. On the myxosporidians of freshwater fishes from Lake Huama, Hubei Province: ii. Descriptions of new species (Myxosporea:Bivalvulida). Acta Zootaxon Sinica. 1992:17:133-50.

31. Griffin MJ, Goodwin AE. Thelohanellus toyamai (syn. Myxobolus toyamai) infecting the gills of koi Cyprinus carpio in the Eastern United States. J Parasitol. 2011;97:493-502.

32. Yokoyama H, Suzuki J, Shirakashi S. Kudoa hexapunctata n. sp. (Myxozoa: Multivalvulida) from the somatic muscle of Pacific bluefin tuna Thunnus orientalis and re-description of $K$. neothunni in yellowfin tuna T. albacares. Parasitol Int. 2014;63:571-9.

33. Molnár K, Marton S, Eszterbauer E, Székely C. Comparative morphological and molecular studies on Myxobolus spp. infecting chub from the River Danube, Hungary, and description of Myxobolus muellericus sp. n. Dis Aquat Organ. 2006;73:49-61.

34. Forró B, Eszterbauer E. Correlation between host specificity and genetic diversity for the muscle-dwelling fish parasite Myxobolus pseudodispar: examples of myxozoan host-shift? Folia Parasitol (Praha). 2016;63:019.

35. Molnár K. Site preference of myxosporean spp. on the fins of some Hungarian fish species. Dis Aquat Organ. 2002;52:123-8.

36. Guo Q, Zhai Y, Gu Z, Liu Y. Histopathological and ultrastructural studies of Myxobolus turpisrotundus from allogynogenetic gibel carp Carassius auratus gibelio in China. Folia Parasitol (Praha). 2016;63:033.

37. Dyková I, Fiala I, Nie P. others. New data on Myxobolus longisporus (Myxozoa: Myxobolidae), a gill infecting parasite of carp, Cyprinus carpio haematopterus, from Chinese lakes. Folia Parasitol (Praha). 2003;50:263-8. 
38. Kudo R. Contributions to the study of parasitic Protozoa. II. Myxobolus toyamai nov. spec., a new myxosporidian parasite in Cyprinus carpio L. J Parasitol. 1917;3:163-70.

39. Yokoyama H, Ogawa K. The resurrection of Myxobolus toyamai with a validation of a stunted polar capsule based on morphological evidence. Parasitol Int. 2015;64:43-7.

Ready to submit your research? Choose BMC and benefit from:

- fast, convenient online submission

- thorough peer review by experienced researchers in your field

- rapid publication on acceptance

- support for research data, including large and complex data types

- gold Open Access which fosters wider collaboration and increased citations

- maximum visibility for your research: over $100 \mathrm{M}$ website views per year 